Full length article

\title{
The effect of social media on firm performance
}

\author{
Rana Tajvidi", Azhdar Karami \\ Bangor Business School, Bangor University, College Road, Bangor, North Wales, LL57 2DG, UK
}

\section{A R T I C L E I N F O}

\section{Article history:}

Received 18 March 2017

Received in revised form

23 August 2017

Accepted 19 September 2017

Available online $\mathrm{xxx}$

\section{Keywords:}

Social media

Branding

Innovation

Firm performance

Hotel industry

\begin{abstract}
A B S T R A C T
This study provides a new perspective on the effect of social media use in SMEs. The purpose of this paper is to investigate the influence of social media on firm performance with mediating role of marketing capabilities in the UK, hotel industry. In this research, a structural equation modelling method has been employed for data analysis. The survey data has been collected by mail survey from a sample of 384 hotels in the UK. Results from the data analysis demonstrate the positive and significant relationship between social media use and firm performance. However, the findings highlighted that marketing capabilities, namely branding and innovation, positively and significantly mediate the association between social media use and firm performance.
\end{abstract}

Crown Copyright ㄷ 2017 Published by Elsevier Ltd. All rights reserved.

\section{Introduction}

In the last two decades, internet innovations have played an important role in business performances (Kim, Li, \& Brymer, 2016). Web 2.0 applications provide the opportunity to transfer internet capability to the social environment where individuals are able to interact online by using social media (Sigala \& Chalkiti, 2014). Social media is an effective cyberspace for accessing reliable and update information (Sigala, 2012). The popularity and enormous use of social media facilitates the online learning and the sharing information (Hur, Kim, Karatepe, \& Lee, 2017). Social media allows the users, without any need to physical presence, to communicate and generate content (Zhang, Guo, Hu, \& Liu, 2017). Moreover, social media has been seen as an effective billboard for a firm's commercial goals and better business performance (Rapp, Beitelspacher, Grewal, \& Hughes, 2013). Most firms are using social media to increase business brand image and brand awareness (Nisar \& Whitehead, 2016; Pentina, Gammoh, Zhang, \& Mallin, 2013). Furthermore, the social media influence company branding strategies which leads to eWOM (electronic word of mouth) (Barreda, Bilgihan, Nusair, \& Okumus, 2015). Therefore, eWOM attracts consumers and enhances their purchasing intention (Xie et al., 2016).

\footnotetext{
* Corresponding author.

E-mail addresses: abpea6@bangor.ac.uk (R. Tajvidi), a.karami@bangor.ac.uk
} (A. Karami).
By using social media, customers have access to different sources of shared information from other customers in regard to their experiences and recommendations. This influences their purchasing decisions (Chen, Fay, \& Wang, 2011). Therefore, the important role of social media in developing relationship and trust with customers, suppliers and potential partners is a significant consideration for firms (Rapp et al., 2013). A firm's involvement in social media offers values for their business including enhanced brand value (Gensler, Völckner, Liu-Thompkins, \& Wiertz, 2013; Hudson, Huang, Roth, \& Madden, 2016; Nisar \& Whitehead, 2016); sales growth (Kumar, Bhaskaran, Mirchandani, \& Shah, 2013); ecommerce and social commerce (Hajli, 2014); customer trust and Stickiness (Zhang et al., 2017); innovation and new product development (Palacios-Marqués, Merigó, \& Soto-Acosta, 2015; Roberts \& Candi, 2014); knowledge sharing (Munar \& Jacobsen, 2014); CRM, customer relationship management, (Rosman \& Stuhura, 2013), eWOM (Ladhari \& Michaud, 2015).

Although previous studies have showed interest in social media values for organizations, there are very limited empirical studies on finding the influence of using social media on the performance of SMEs in the hospitality industry. W. G. Kim, Lim, and Brymer (2015), argue that researchers should try to focus on the identification of derivers and moderators that produce impact on business performance rather than focusing on social media principles. Moreover, according to the resource based view (RBV), firm capabilities and resources could create sustained competitive advantages (Davcik \& 
Sharma, 2016). Therefore, social media enhance SMEs capabilities to increase their performance (Trainor, Andzulis, Rapp, \& Agnihotri, 2014). The resource based view of firm provides a foundation for the link between social media usage and value creation for small and medium sized enterprises (Palacios-Marqués et al., 2015). Besides, social media use creates value for SMEs in regard to internal operations, marketing, customer services, and sales which are very important factors in case of small and medium sized enterprises (Gensler et al., 2013; Schaupp \& Bélanger, 2013).

\subsection{Hospitality industry}

By nineteen century, the tourism and hospitality industry had grown rapidly and steadily towards becoming a global industry (Wood, 2017). The hospitality industry is one of the fastest growing industries in the UK (Pappas \& Apostolakis, 2016). This industry contributes significantly to the economic growth of every country and is one of the fast growing industries in the United Kingdom (Pappas \& Apostolakis, 2016). The total economic impact of the tourism and hospitality industry in the UK is considered very high (Hajli \& Lin, 2014). According to Oxford Economics report, Economics (2015):

"The total GDP contribution of the hospitality industry in 2015 is estimated to have been $£ 143$ billion. The industry also supported employment for an estimated 4.6 million people" (Economics, 2015, P.24). Moreover, they forecast the hospitality industry to grow to 3.44 million direct jobs by 2020 .

In the past, before the popularity of social media, travel consumers were reliant on travel journalism and traditional media to find help for choosing the best and most exciting places and hotels to visit, which are now replaced by internet (Zeng \& Gerritsen, 2014). Nowadays, social media are playing the role of information provider for travel related businesses and the consumers are using internet to plan their travel and leisure trips (Munar \& Jacobsen, 2014). Therefore, it is very important for businesses to know how to deal with social media and the effects it has on potential customers purchasing decisions (Marco-Lajara, del Carmen ZaragozaSáez, Claver-Cortés, Úbeda-García, \& García-Lillo, 2017). One of those businesses, which is very competitive, is the hotel industry where customers are located geographically far from the offered products or services (Sigala \& Chalkiti, 2014). In the hotel industry, social media provide advantages for firms such as sales growth, faster direct communication with customers, efficient distribution and procurement, high customer satisfaction, cost reduction and enhanced brand image (Melián-González \& Bulchand-Gidumal, 2016; Okazaki, Andreu, \& Campo, 2017).

A strong presence within social media allows hotels to access to their potential customers directly without spending time and cost (Su, Swanson, \& Chen, 2016). Moreover, they can update their promotions, events and offered services more frequently (Hudson \& Thal, 2013). Also, the international visitors would share their first-hand experiences with the fellow consumers of hotels and this information has been considered useful and reliable for planning to future journeys (Marco-Lajara et al., 2017). On the other hand, hotel quest's created contents on social media helps businesses to understand customers' needs and desires which in turn leads to offering better services (Munar \& Jacobsen, 2014).

Thus, in the literature, the importance of social media for hotels is explicit (Guizzardi et al., 2016). Despite the advantages of social media for hotels, still there are very few empirical studies on investigating how engagement in social media can affect hotels performance. This study will cover this gap in literature by focusing on hotels social media use and how engagement in social media can be valuable for their performance.

\section{Theoretical background}

\subsection{Resource based view}

The literature on social media has been viewed from different theoretical perspectives. The theories are based on adaption of social media at the individual level or organizational level (Schaupp \& Bélanger, 2013). Theories on individual level such as Theory of Planned Behaviour (TPB) by Ajzen (1991); Technology Accepted Model (TAM) (Pavlou, 2003) and on organizational level as Technology Organization Environment (TOE) theory (Tornatzky, Fleischer, \& Chakrabarti, 1990) and resource based view (RBV) theory (Barney, 2001). RBV is a theory that has been used mostly in recent years to serve as a foundation for the link between social media and their value for firms. The theory of resource based view supports the assumption that obtaining competitive advantage for firm depend on the application of the firm's bundle of productive resources (Barney, 2001; Wernerfelt, 1984). According to this theory, firm resources and capabilities that are valuable, rare, inimitable and distinctive are considered as an essential source of competitive advantage and superior performance (Barney, 2001; Peteraf, 1993). Resources are the central drivers of the resource based view on the hotel industry (Gannon, Roper, \& Doherty, 2015). There are different resources in the tourism and hospitality industry including physical resources (building exteriors and interiors, geographic location, facilities, and finances), human resources (staff and managerial skills) and organizational resources (culture, business processes and strategies, information technology, knowledge sharing) (Gannon et al., 2015; Leonidou, Leonidou, Fotiadis, \& Zeriti, 2013). These different types of resources contribute to value creation strategies for travel-related firms (Fraj, Matute, \& Melero, 2015). On the other hand, capabilities refer to the skills of a firm in taking advantage of its resources and assets. Therefore, social media provide the opportunity to maximize benefit from a firm's IT resources and networking capabilities (Trainor et al., 2014). In the hotel industry, knowledge acquired by firm's networking activities can promote organizational performance (Harrington \& Ottenbacher, 2011). Online social platforms are playing critical role in facilitating the sharing knowledge among firm and consumers (Sigala \& Chalkiti, 2012). Shared information on social media is very effective in enhancing the purchasing and decision making behaviour of customers in travel related firms (Barreda et al., 2015). Besides, social media have been defined as an internet based resource capability, a powerful "enabling technology" that provides synergies a complementarity with other resources in firms (Sigala, 2012).

\subsection{Social media and firm performance}

In recent decades, using cyberspace and web-technology has become a common practice in all businesses (Zhang et al., 2017). Organizations are empowered to contact their clients anytime from anywhere by Internet (Chen et al., 2011). Kaplan and Haenlein (2010, p. 63) have defined social media as "a group of Internetbased applications that build on the ideological and technological foundations of Web 2.0, and that allow the creation and exchange of user-generated content".

Social media includes many different forms of online applications such as social networking sites (SNSs), blogs, forums, microblogs, photo sharing, video sharing, product/service reviews, evaluation communities and social gambling (Aichner \& Jacob, 2015). Social media facilitates the information sharing and content generation process by individuals (Kim \& Johnson, 2016). People are using different online networks such as Facebook, YouTube, Wikipedia, Twitter, Instagram, TripAdvisor, online 
forums, ratings and review forums to share their experiences and interact with other users (Chen et al., 2011). Indeed, social media attract information seekers to obtain information about the product/service which they are going to purchase and leads to an enhancement of the buying intention of consumers (Hajli, 2013). On the other hand, social media as a communication channel help firms to accomplish different organizational objectives including marketing, PR, advertising, branding, customer service, human resources and problem solving (Kim \& Park, 2013; Nisar \& Whitehead, 2016). Accordingly, social media have been considered as an effective platform for enterprises to connect with large number of potential customers in order to spread their business information about their businesses (Schaupp \& Bélanger, 2013). The development of online communities has expanded the interconnectivity between businesses and consumers and enables them to make rapid international communications (Aichner \& Jacob, 2015). Moreover, social media impact on firms brand position, brand awareness, customer's loyalty and customers purchasing decisions (Barreda et al., 2015; Nisar \& Whitehead, 2016).

Social media adaption by firms creates a great networks among businesses, customers and suppliers (Siamagka, Christodoulides, Michaelidou, \& Valvi, 2015). Based on network approach, firms are taking advantage of networking activities which lead to superior performance (Naudé, Zaefarian, Tavani, Neghabi, \& Zaefarian, 2014). The majority of previous studies regarding networking approach emphasised on networking advantages for firms (Ladkin \& Buhalis, 2016; Naudé et al., 2014; Trainor et al., 2014; Watson, 2007). However, less attention has been paid to the online networking values for SMEs performance (Hajli, 2014; Wamba \& Carter, 2016). Given that small and medium sized enterprises are economic engine of most of countries (Cowling, Liu, Ledger, \& Zhang, 2015), previous studies mainly have focused on the adaption (Durkin, McGowan, \& McKeown, 2013; Wamba \& Carter, 2016) and benefits and barriers (Michaelidou, Siamagka, \& Christodoulides, 2011) of social media in SMEs context. Moreover, in regard to the hotel industry, there are few studies that consider the effect of social media use on improving firm performance (Harrington \& Ottenbacher, 2011; Zhang et al., 2017).

Social media fundamentally affect the hotel industry. According to Jeong \& Mindy Jeon (2008) it is a free market research tool, as focusing on customers evaluation and comments on different social networking sites provides an idea to hotel managers about their overall business performance. Trough social media, hotels can positively affect the purchasing and decision making behaviour of their potential customers (Hajli, 2015). High level engagement on social media by the hotel industry helps to make awareness about business brand and new product/services (Kim et al., 2016). Hospitality firms are encouraging their customers to like, share, comment and rate their business on different social networking platforms which leads to brand awareness among users (Gensler et al., 2013). In addition to branding, social media contributes to promotion and public relations (Trusov, Bucklin, \& Pauwels, 2009). The other benefit drived form social media for enhancing firm performance is the change of social media to a booking channel for hospitality firms (Harrigan, Evers, Miles, \& Daly, 2017). Nowadays, most customers are encouraged to book either directly online from social media or via a direct link to booking websites. This possibility inherent in social media, will positively affect the sales growth of hotels (Harrigan et al., 2017). In addition, reaching great number of customers globally will contribute to internationalization and leads to high sales volume and consequently higher profitability (Seth, 2012).

Moreover, eWOM (electronic word of mouth) generated by social media, is a very strong marketing tool for small hotels effecting sale growth, branding and profitability (Litvin, Goldsmith, \& Pan,
2008). As small hotels have budget limitation on spending for marketing campaigns or print advertisement, social media use will be very beneficial for their growth (Litvin et al., 2008; O'Connor, 2008).

In general, according to literature social media engagement plays important role in influencing the hotel industry. Still, despite the findings made by the above studies concerning the hotel industry, understanding the impacts of social media use on firm's performance is still limited. This study is focusing on social media use by hotels in order to find its possible effect on improving firm performance. Therefore, online and offline networks have been compared. By comparing the data analysis results, the research intents to find more accurate information on which channel is more preferable and popular for hotels; how the hotel industry is engaging with them and which one is more effective for performance. Hence, the first hypothesis of study has been developed as below:

H1. There is a positive relationship between social media use and firm performance

H1a. Online networks has positive effect on firm performance

H1b. Offline networks has positive effect on firm performance

\subsection{The mediating role of marketing capability}

According to RBV literature, organizational capabilities are identified as core determinants for business performance and achieving competitive advantage (Wong \& Karia, 2010). Recourse based view suggests that inter-firm capabilities as technology, marketing and operational have been seen as key elements to organizational success (Barney, 2001).

The existing marketing literature reveals that marketing capabilities (MC) are one of the decisive drivers of firm performance (Su, Peng, Shen, \& Xiao, 2013). Therefore, marketing capabilities are 'immobile' (Capron \& Hulland, 1999), 'inimitable' (Bharadwaj, Varadarajan, \& Fahy, 1993) and 'non-substitutable' (Moorman \& Rust, 1999). Furthermore, it is claimed that, the firms with greater marketing capabilities can obtain sustainable completive advantage and superior performance (Wong \& Karia, 2010). Morgan, Slotegraaf, and Vorhies (2009) revealed marketing planning and marketing implementation as two elements of firm marketing capabilities (MC) that have positive influence on business performance. On the other hand (Morgan, 2012), argued that marketing capabilities have direct complementary impact on profit growth in a firm. In addition, in a study by Chang, Park, and Chaiy (2010) investigating the mediating role of marketing capabilities in relationship between customer relationship management (CRM) and performance, it was revealed that MC mediates the relationship between CRM and firm performance positively. Furthermore, a study (Ahmed, Kristal, \& Pagell, 2014) showed that marketing capabilities contribute to improving firm performance outcomes in different economic conditions.

However, organizations are embedded in networks and are making links with their customers and other businesses. Social media provides opportunity for the hotel industry to make strong networks and improve their capabilities to effect on performance (Gensler et al., 2013). Moreover, it has been argued that one of the important methods for firms to obtain the competitive advantage is improving network (Boso, Story, \& Cadogan, 2013). Online networking impacts on firm performance by developing strong relationships with firm clients, influencing customer's purchasing intention and accessing to shared knowledge (Walter, Auer, \& Ritter, 2006). 
Despite scholarly attention in literature toward marketing capabilities and firm performance, the literature suggest that evaluation of marketing capabilities effects on firm performance in the context of hotel industry continue to lag (Leonidou et al., 2013; Odoom et al., 2017; Ramanathan, Ramanathan, \& Zhang, 2016). Furthermore, the majority of previous studies have focused on midlevel marketing capabilities as marketing mix (Aaker, 1996; Ahmed et al., 2014; Keller, 1993; Su et al., 2013) rather than to high-level marketing capabilities (Merrilees, Rundle-Thiele, \& Lye, 2011). In the current study marketing capability has been considered by using two high-level capabilities: innovation and branding (Merrilees et al., 2011). The innovation and branding capabilities are crucial for obtaining competitive advantage and superior performance (Hogan \& Coote, 2014). Hence, the research aims to find how two high-level marketing capabilities namely branding and innovation, are playing a key role in explaining the firm performance along with social media. Considering the paucity of studies on this area in the hotel industry, the second hypothesis and sub hypotheses of study are proposed as bellow:

H2. Marketing capabilities mediate the relationship between social media and firm performance.

H2a. Innovation capability has positive effect on firm performance

H2b. Branding capability has positive effect on firm performance

After synthesizing the literature the study conceptual model has been developed as Fig. 1 to examine the relationships between the constructs of this research, namely social media, marketing capabilities and performance (see Fig. 1).

\section{Method}

\subsection{Sample and data}

In this research, we used Structural Equation Modelling (SEM) to test the proposed conceptual framework and the hypotheses. Our analysis is presented in a transparent and sequential manner, allowing for clarity in conceptual framework and results. Quantitative survey data were collected from micro (1-9 employees), small (10-49 employees) and medium (50-249 employees) sized firms. A survey was distributed to SMEs operating in hotel industry across the UK in 2015. The sample was drawn from a database covering the list of all UK hotels which included 5000 hotels, B\&Bs, inns and guest houses. A total number of 2435 sample hotels were randomly selected using stratified random sampling method. Prior to the distribution of the questionnaire, a pilot study was conducted using a sample of 15 hotels. The refined questionnaires have been distributed by post and a total number of 384 questionnaires were collected giving a $15.77 \%$ response rate. The final questionnaire consisted of four main sections; demographic information of

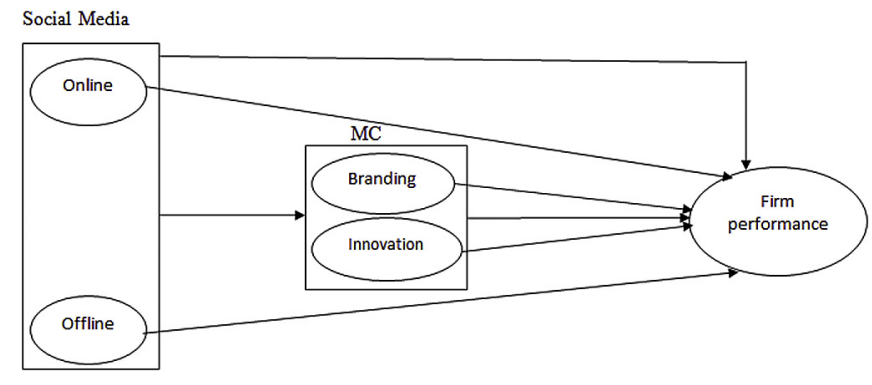

Fig. 1. Conceptual research model. respondents such as gender, age, education level and size of firm, use of online and offline networks, branding and innovation as constructs to measure the marketing capabilities of firms and measures of the firm's performance over the past three years. Questions were developed using 5 point Likert scales. In order to examine the use of social media the Likert scale ranged from "never" to "always" and for marketing capabilities and firm performance the range was from "strongly disagree" to "strongly agree".

\subsection{Measures}

The current study aimed to investigate the social media use in hotel industry. The survey instrument used comprises four previous independent, validated scales. The networking has been categorised into two dimensions, online versus offline networks. The aim was to identify both hotels' preferences in using social networks and also their purposes. Besides, the respondents were asked about their use of social networking sites such as LinkedIn, Facebook, Twitter or travel communities as TripAdvisor (Harris, Rae, \& Misner, 2012; Xie et al., 2016; Yen \& Tang, 2015) and offline networks such as face-to-face meetings, participating in exhibitions/ events, using traditional media as TV/radio, magazines or print advertisement (Harris et al., 2012; Ring, Tkaczynski, \& Dolnicar, 2016). The respondents were asked to indicate the response that most closely described the networking behaviours within their firm. The marketing capability construct was measured by using two high-level capabilities including branding (Agostini, Filippini, \& Nosella, 2015; Merrilees et al., 2011) and innovation (Hooley, Greenley, Cadogan, \& Fahy, 2005; Nieves \& Segarra-Ciprés, 2015). The respondents were asked to indicate their perceptions with regard to the items pertaining to brand capability and innovation capability in their firm. The scale for measuring the firm performance has been adapted from Watson (2012). The respondents were asked to rate the performance of theirs firm in terms of growth (Kim et al., 2015) and profitability (Yen \& Tang, 2015) (see Table 1).

\section{Results}

\subsection{Descriptive analysis}

The general information about the characteristics of respondents including their age, gender, organizational position and the characteristics of the studied firms including their location, size, and service type is shown in Table 2.

In this study the majority of respondents were male (226) having a CEO position (55.7\%) in the fourth age group of 50 or more (51\%). Most hotels studied were small (147) or medium sized (140). Respondents were from throughout the UK but mainly from England (54.7\%), then Wales (21\%) and Scotland (18\%). Majority of the firms studied (80.5\%) were hotels. The remaining were including B\&Bs (8\%), Guest Houses (6.5\%) and Inns (5\%). Furthermore, the results show that the majority of respondents (234) have 20 years or more working experiences. The educational level of the respondents were $38.5 \%$ undergraduate, $27.9 \%$ masters and $\mathrm{PhDs}$, $25.3 \%$ A level or less and $8.3 \%$ other.

The descriptive statistics for the research constructs in the conceptual model and the bi-variate correlations among them are shown in Table 3. This bivariate correlation analysis has been carried out to test the correlations between the independent variables indicated as a need for an SEM-type analytical approach to test the hypotheses. 
Table 1

The variables and measurement scales.

\begin{tabular}{|c|c|c|c|}
\hline Variable & Constructs & Item & References \\
\hline \multirow[t]{2}{*}{ Social Media (SM) } & Online & $\begin{array}{l}\text { - Facebook } \\
\text { - LinkedIn } \\
\text { - Twitter } \\
\text { - YouTube } \\
\text { - Instagram } \\
\text { - Pinterest } \\
\text { - Google + } \\
\text { - TripAdvisor }\end{array}$ & (Harris et al., 2012; Xie et al., 2016; Yen \& Tang, 2015) \\
\hline & Offline & $\begin{array}{l}\text { - Face to face meetings } \\
\text { - TV/Radio } \\
\text { - Magazines } \\
\text { - Exhibitions/Events/festivals } \\
\text { - Print advertisement }\end{array}$ & (Harris et al., 2012; Ring et al., 2016) \\
\hline \multirow[t]{2}{*}{ Marketing Capabilities (MC) } & Branding & $\begin{array}{l}\text { - Able to identify a simple brand meaning } \\
\text { - Using branding as an operational tool } \\
\text { - Able to communicate a consistent brand meaning } \\
\text { - Treating the brand as assets } \\
\text { - Supporting brand through staff }\end{array}$ & $\begin{array}{l}\text { (Merrilees et al., 2011) } \\
\text { (Agostini et al., 2015) }\end{array}$ \\
\hline & Innovation & $\begin{array}{l}\text { - Developing new ideas to help customers } \\
\text { - Able to fast track new offerings to customers } \\
\text { - Able to manage processes to keep costs down } \\
\text { - Able to package a total solution to solve a customer problem }\end{array}$ & (Hooley et al., 2005; Nieves \& Segarra-Ciprés, 2015) \\
\hline \multirow[t]{2}{*}{ Firm Performance (FP) } & Growth & $\begin{array}{l}\text { - Increase in market share over the past } 3 \text { years } \\
\text { - Increase in annual turnover over the past } 3 \text { years } \\
\text { - Number of employees over the past } 3 \text { years }\end{array}$ & (Kim et al., 2016; Watson, 2012) \\
\hline & Profitability & $\begin{array}{l}\text { - Achieving firm profit goals over the past } 3 \text { years } \\
\text { - Having a better return on investment over the past } 3 \text { years } \\
\text { - Increase in total income over the past } 3 \text { years }\end{array}$ & (Watson, 2012; Yu, Ramanathan, \& Nath, 2014) \\
\hline
\end{tabular}

Table 2

Demographic profile of respondents.

\begin{tabular}{|c|c|c|c|c|c|c|c|c|}
\hline Respondent age & $\mathrm{n}$ & $\%$ & Position & $\mathrm{n}$ & $\%$ & Gender & $\mathrm{n}$ & $\%$ \\
\hline $20-29$ & 43 & 11.2 & CEO & 214 & 55.7 & Male & 226 & 58.9 \\
\hline $30-39$ & 58 & 15.1 & Middle manager & 135 & 35.2 & Female & 158 & 41.1 \\
\hline $40-49$ & 87 & 22.7 & Supervisor & 16 & 4.2 & & & \\
\hline 50 or more & 196 & 51.0 & Other & 19 & 4.9 & & & \\
\hline Firm size & $\mathrm{n}$ & $\%$ & Firm location & $\mathrm{n}$ & $\%$ & Service type & $\mathrm{n}$ & $\%$ \\
\hline Micro firm (1-9) & 97 & 25.3 & England & 210 & 54.7 & Hotel & 309 & 80.5 \\
\hline \multirow[t]{2}{*}{ Small firm $(10-49)$} & 147 & 38.3 & Wales & 85 & 22.1 & $\mathrm{~B} \& \mathrm{~B}$ & 31 & 8.1 \\
\hline & & & Northern Ireland & 20 & 5.2 & Inn & 19 & 4.9 \\
\hline Medium (50-250) & 140 & 36.5 & Scotland & 69 & 18.0 & Guest house & 25 & 6.5 \\
\hline
\end{tabular}

Table 3

Descriptive statistics and correlations matrix.

\begin{tabular}{|c|c|c|c|c|c|c|c|c|c|c|c|}
\hline & M & SD & 1 & 2 & 3 & 4 & 5 & 6 & 7 & 8 & 9 \\
\hline 1.Online & 3.70 & 0.53 & 1 & & & & & & & & \\
\hline 2.Offline & 2.8896 & 0.95 & $.531^{* *}$ & 1 & & & & & & & \\
\hline 3.Branding & 3.9301 & 0.69 & $.434^{* *}$ & $.375^{* *}$ & 1 & & & & & & \\
\hline 4.Innovation & 4.1654 & 0.49 & $.353^{* *}$ & $.199^{* *}$ & $.321^{* *}$ & 1 & & & & & \\
\hline 5.Growth & 4.2405 & 0.45 & .114 & $.163^{* *}$ & $.174^{* *}$ & $.250^{* *}$ & 1 & & & & \\
\hline 6.Profitability & 4.1777 & 0.47 & .144 & $.215^{* *}$ & $.181^{* *}$ & $.246^{* *}$ & $.537^{* *}$ & 1 & & & \\
\hline 7.Social media & 3.3263 & 0.71 & $.821^{* *}$ & $.920^{* *}$ & $.454^{* *}$ & $.297^{* *}$ & $.163^{* *}$ & $.212^{* *}$ & 1 & & \\
\hline 8.Marketing capabilities & 4.0461 & 0.60 & .442 & $.322^{* *}$ & $.767^{* *}$ & $.632^{* *}$ & $.211^{* *}$ & .079 & $.422^{* *}$ & 1 & \\
\hline 9.Firm Performance & 4.2054 & 0.41 & .046 & $.221^{* *}$ & $.202^{* *}$ & $.280^{* *}$ & $.831^{* *}$ & $.915^{* *}$ & $.218^{* *}$ & $.152^{* *}$ & 1 \\
\hline
\end{tabular}

**. Correlation is significant at the 0.01 level (2-tailed).

*. Correlation is significant at the 0.05 level (2-tailed).

\subsection{Data measurement model}

Structural Equations Modelling (SEM) was used to test the direct and indirect relationships between variables. In the first step, the data were analysed by measuring the central tendency and dispersion. In the second step we dealt with assessing the validity and reliability of the scales (see Table 4). For evaluating, the reliability Cronbach's alpha was used and all items were above the threshold level 0.70 which is an accepted rate (Nunnally, 1978). Thus, rate and the reliability of data have been confirmed. In the third step, the principle component analysis on each item was conducted. Then the convergent validity was estimated at the average variance extract (AVE). All the items exceeded 0.5 which is a recommended rate (Bagozzi, Yi, \& Phillips, 1991) and is satisfactory. The composite reliability of the constructs are above 0.6 which is suggested level by Bagozzi and Yi (1988). 
Table 4

Measurement model.

\begin{tabular}{|c|c|c|c|c|c|}
\hline Construct & Indicators & Factor Loading* & Composite Reliability $^{* *}$ & $\mathrm{R}^{2 * * *}$ & $\operatorname{AVE}^{* * * *}$ \\
\hline \multirow[t]{10}{*}{ SM } & ONS1 & 0.554 & 0.84 & 0.49 & 0.84 \\
\hline & ONS2 & 0.568 & & 0.50 & \\
\hline & ONS3 & 0.613 & & 0.48 & \\
\hline & ONS4 & 0.500 & & 0.52 & \\
\hline & ONS5 & 0.575 & & 0.34 & \\
\hline & OFS6 & 0.596 & & 0.31 & \\
\hline & OFS7 & 0.712 & & 0.61 & \\
\hline & OFS8 & 0.540 & & 0.40 & \\
\hline & OFS9 & 0.765 & & 0.56 & \\
\hline & OFS10 & 0.768 & & 0.59 & \\
\hline \multirow[t]{10}{*}{ MC } & BR1 & 0.745 & 0.63 & 0.68 & 0.79 \\
\hline & BR2 & 0.721 & & 0.66 & \\
\hline & BR3 & 0.635 & & 0.48 & \\
\hline & BR4 & 0.729 & & 0.67 & \\
\hline & BR5 & 0.720 & & 0.64 & \\
\hline & BR6 & 0.539 & & 0.57 & \\
\hline & IN1 & 0.749 & & 0.46 & \\
\hline & IN2 & 0.717 & & 0.52 & \\
\hline & IN3 & 0.777 & & 0.50 & \\
\hline & IN4 & 0.592 & & 0.65 & \\
\hline \multirow[t]{7}{*}{ FP } & FP1 & 0.501 & 0.81 & 0.41 & 0.76 \\
\hline & FP2 & 0.580 & & 0.53 & \\
\hline & FP3 & 0.518 & & 0.48 & \\
\hline & FP4 & 0.585 & & 0.51 & \\
\hline & FP5 & 0.575 & & 0.50 & \\
\hline & FP6 & 0.553 & & 0.49 & \\
\hline & FP7 & 0.667 & & 0.63 & \\
\hline
\end{tabular}

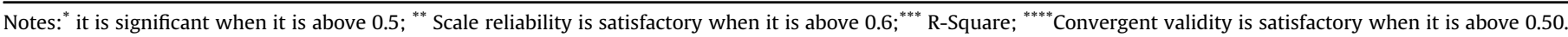

\subsection{Confirmatory factor analysis}

The confirmatory factor analyses (CFA) is a recommended tool for testing whether the data fits the model of research or not (Kline, 1998). In this study CFA was used to validate the research scales. There are different indices that show the fitness of model, but the suggested tools by Kline (1998) is the absolute fit, which is indicated by the Chi-squared test, GFI, AGFI and RMSEA.

Table 5 presents the result of the confirmatory factor analyses. The results show that the scales are unidimensional and have high validity and reliability.

To assess the validity and reliability of measures, CFI was used for each one of the constructs (Jöreskog \& Sörbom, 1996). The measurement model shows high reliability and validity of the scales (Table 5) is evidenced by Cronbach's alpha which is higher than 0.7, a recommended level by Hair, Sarstedt, Ringle, and Mena (2012). As shown in Table 5, the measurement model shows the appropriate indexes of goodness-fit: a non-significant $\chi^{2}$, GFI, CFI and IFI above 0.9 and RMSEA below 0.08 .

\subsection{Estimation model and results}

SEM is used to assess the relationships between the variables simultaneously. The fit indices show a good fit for the model: ChiSquare $=17.83, \mathrm{p}=0.00$, (Goodness of Fit Index) GEI $=0.98$, Incremental Fit Index (IFI) $=0.98$, comparative Fit Index $(\mathrm{CFI})=0.98$, Standardized PMR $=0.093$, RMSEA $=0.35$. It can be concluded that the model has an acceptable fit for testing the hypotheses. Fig. 2 demonstrates that all paths are significant. The results provide support for all hypotheses. Table 6 shows estimates of the SEM parameters. All parameters are satisfactory and all hypotheses are supported. Social media use positively affects firm performance and online social media use has a significant positive influence on performance. Innovation and branding as two marketing capability constructs, positively affect firm performance.

The results of analysing show that the hypotheses are supported and there are positive relationships between variables (Table 5). The result of path analysis with SEM show that in general, social media use positively effects the firm performance $(\beta=0.33$; $\mathrm{P}=0.00$ ). Therefore, the hotels that use social media increase their profitability and growth. However the result shows that both online networks $(\beta=0.73 ; \mathrm{P}=0.00$ ) and offline networks $(\beta=0.64$; $\mathrm{P}=0.05$ ) positively impact on firm performance. However, use of online social media has a stronger effect on firm performance than offline methods. It also has been found that marketing capabilities has strong mediating effect on the relationship between social media use and firm performance $(\beta=0.90 ; \mathrm{P}<0.00)$. The path analysis result revealed that use of social media is partially affect firm performance, but the hotels that possess marketing capabilities benefit from using online social media to increase their performance. In this regard, the effect of branding capability $(\beta=0.66$; $\mathrm{P}<0.00$ ) on the firm performance was stronger than innovation capability $(\beta=0.49 ; \mathrm{P}<0.00)$. The mediating role of marketing capabilities will be discussed in detail in the next section.

Table 5

Confirmatory factor analysis (CFA).

\begin{tabular}{|c|c|c|c|c|c|c|c|c|c|}
\hline Variables & Mean & SD & Items & $\chi^{2}$ & GFI & AGFI & RMSEA & Alpha Cronbach & $\mathrm{SCR}^{\mathrm{a}}$ \\
\hline Social networking & 3.32 & 0.71 & 10 & 490.70 & 0.91 & 0.89 & 0.000 & 0.860 & 0.85 \\
\hline Marketing capability & 4.04 & 0.60 & 10 & 322.09 & 0.92 & 0.88 & 0.014 & 0.801 & 0.69 \\
\hline Firm performance & 4.2054 & 0.41 & 7 & 80.79 & 0.94 & 0.89 & 0.011 & 0.889 & 0.82 \\
\hline
\end{tabular}

\footnotetext{
a Scale composite reliability.
} 
Social Media

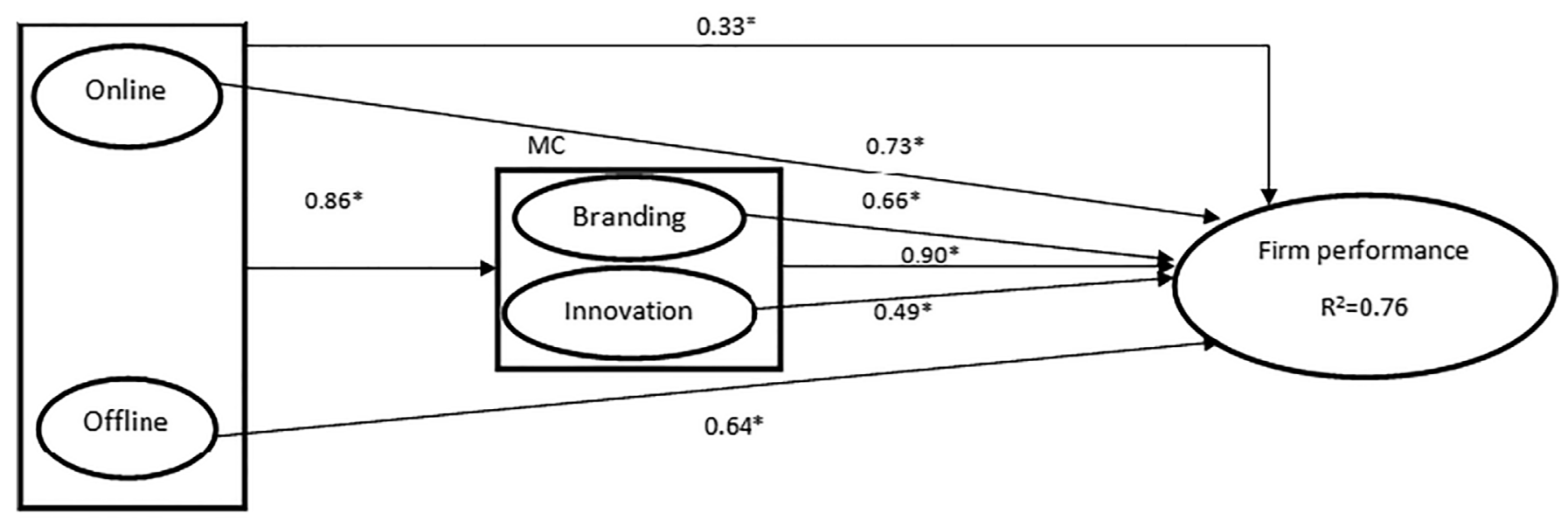

*Coefficients are significant at the level of $5 \%$

Fig. 2. Path analysis result.

Table 6

Path estimates for structural equation model.

\begin{tabular}{|c|c|c|c|c|}
\hline Hypothesis & $\beta$ & t-value & Sig & result \\
\hline H1: Social media use $\rightarrow$ firm performance & 0.33 & 3.85 & 0.00 & Supported \\
\hline H1a:Online $\rightarrow$ firm performance & 0.73 & 13.81 & 0.00 & Supported \\
\hline H1b: Offline $\rightarrow$ firm performance & 0.64 & 11.31 & 0.00 & Supported \\
\hline H2:Marketing capabilities $\rightarrow$ firm performance & 0.90 & 2.49 & 0.00 & Supported \\
\hline H2a: Branding $\rightarrow$ firm performance & 0.66 & 4.26 & 0.00 & Supported \\
\hline H2b: Innovation $\rightarrow$ firm performance & 0.49 & 4.47 & 0.00 & Supported \\
\hline
\end{tabular}

In order to test the mediating role of marketing capabilities, namely branding and innovation, we used the MacKinnon, Lockwood, Hoffman, West, and Sheets (2002) approach. According to MacKinnon et al. (2002) Z mediates the link between X and Y, if the direct path between $\mathrm{X}$ to $\mathrm{Z}$ and from $\mathrm{Z}$ to $\mathrm{Y}$ were significant. The result shows that the direct path from social media use to marketing capabilities $(\beta=0.86, \mathrm{P}=0.00)$ and the direct path from marketing capabilities to firm performance $(\beta=0.90, \mathrm{P}=0.00)$ are positive and significant. Therefore, the $\mathrm{H} 2$ meets the criteria for mediation. In the next phase, we used the three-equation test of Baron and Kenny (1986) which includes four steps. In step 1 independent variable, social media use, should affect the mediating variable namely marketing capabilities. In step two the independent variable, social media use, should have direct and significant effect on dependent variable, firm performance. The third step requires testing the effects of independent variable and mediating variable on dependent variable. In this study, all three conditions were met. The final step of this approach requiring testing the influence of independent variable drop considerably and it should done by comparing the second and third sets of regressions. This condition also was met and the beta coefficient of independent data

Table 7

Three-equation mediation tests approach.

\begin{tabular}{ll}
\hline Step & Multiple regression results \\
\hline Step 1 & Marketing Capability $=0.42$ Social media \\
Step 2 & Firm Performance $=0.21$ Social media \\
Step 3 & Firm Performance $=0.12$ Social media +0.13 Marketing Capability \\
\hline
\end{tabular}

All the beta coefficients are significant at the level of $5 \%$. (social media use) dropped from 0.21 to 0.12 (Table 7). Therefore, according to this test, all four conditions were met and marketing capabilities mediate the effect of social media use on firm performance. All the beta coefficients are significant at the level of $5 \%$.

\section{Discussion and conclusion}

This research aims to contribute to the understanding of social media use behaviour in SMEs concentrating on hotels in the United Kingdom. Use of social media has become one of the most dominant tools for marketing and networking for firms operating in the hotel industry. However, reviewing and synthesizing the literature indicate that there is a gap in the area of social media use behaviour of SMEs in dealing with online networks to increase their performance. Moreover, the research struggles to explain how two key marketing capabilities of SMEs as branding and innovation are playing a central role in explaining firm performance along with social media. In this paper, we argue and confirm that use of social media results in better performance for the firms, but their performance can be enhanced if the firms develop and possess marketing capabilities namely branding and innovation capabilities.

A number of interesting findings are highlighted from the results of the data analysis. It has been found that use of social media has positive effect on SMEs performance (H1). Dealing with social media for bookings and marketing activities has positive and significant effect on overall performance of studied firms. The results have similarities with the finding of Cervellon \& Galipienzo (2015); Garrido-Moreno \& Lockett (2016) which find the positive effect of social media for improving firm success and better performance. Moreover, in a study by Schniederjans, Cao, and Schniederjans 
(2013) the positive effect of using social media on financial performance of the firms has been highlighted. In addition, these results are comparable to findings of Harris et al. (2012) who argued that SMEs are using a combination of offline and online networks for their business activities such as marketing and sales. They revealed that participants are interested in both types of networks. Face-to-face meetings and events are the most favourite type of traditional media.

The other important finding is supporting the mediating role of marketing capabilities on the relationship between social media use and hotels performance ( $\mathrm{H} 2)$. The findings are in consistent with studies such as (Martínez-Román, Tamayo, Gamero, \& Romero, 2015; Merrilees et al., 2011; Michaelidou et al., 2011; Yu et al., 2014).

A research by Merrilees et al. (2011) who highlighted the positive influence of branding and innovation as two high level marketing capabilities on firm marketing performance in SMEs. Similarly, in a study by Michaelidou et al. (2011) it has been revealed that social media practices are used as a marketing tools and SMEs are using SNSs to achieve brand objectives. Additionally, Martínez-Román et al. (2015) claimed that, marketing capability in hospitality industry contributes to profitability. Moreover, they believe that there is a positive liner relationship between firm performance and offering innovative services.

Our analysis revealed that branding as one of marketing capability has more significant effect than innovation on SMEs performance. Furthermore, although hotels are using social media and online social networks more than other networks, still using offline networks especially face to face meeting are very common among them. It is concluded that small and medium sized firms operating in the hotel industry in UK prefer to use the online networking sites such as Facebook and Twitter to make contact with customers and their business partners rather than use offline networks. These online networks are important, but they need to be put into good use to fully recoup their advantages. Using social networking sites significantly affect branding and innovation capabilities of the firms studied and it in turn consequently leads them to better performance.

\section{Academic and practical implications}

The results of this study bear practical implications. In terms of practical contribution, this research gives insight for SMEs and specially hotel/owner/managers that employing chosen social media for their networking positively improves and enhances their business performance. Access to online social networks and internet is not equivalent to fully utilising those sources. The firms need to develop their branding and innovation marketing capabilities to make most of the available social media. However, we found that using social media improves the firms' marketing capabilities namely branding and innovation capabilities, which lead again to increased performance.

The theoretical contribution of this paper is to contribute to the social media networking and marketing literature in SMEs. In this study, innovation and branding capabilities have been conceptualised in marketing context. This study confirms the fully mediating role of branding and innovation capabilities in the relationship between social media use and performance in SMEs operating in hotel industry.

\section{Limitations and avenue for future studies}

This study is confined to a single industry and needs replication, but focusing on other industries. The importance of social media might vary in other contexts, other industries and other countries.
Future studies test the results of current study in other hospitality sectors as restaurants or clubs. In addition, social media might have a different impact on different grades of hotels e.g. luxury or economy hotels. Studying the effect of social media on consumerbased brand equity, financial-based brand equity, and customer lifetime value are also potentially fruitful avenues for further research. In addition, investigating customer relationship management (CRM), and advertising are needed along with the effect of social media use.

\section{References}

Aaker, D. A. (1996). Measuring brand equity across products and markets. Californic management Review, 38(3), 102-120.

Agostini, L., Filippini, R., \& Nosella, A. (2015). Brand-building efforts and their association with SME sales performance. Journal of Small Business Management 53(S1), 161-173.

Ahmed, M. U., Kristal, M. M., \& Pagell, M. (2014). Impact of operational and marketing capabilities on firm performance: Evidence from economic growth and downturns. International Journal of Production Economics, 154, 59-71.

Aichner, T., \& Jacob, F. (2015). Measuring the degree of corporate social media use International Journal of Market Research, 57(2), 257-275.

Ajzen, I. (1991). The theory of planned behavior. Organizational Behavior and Human Decision Processes, 50(2), 179-211.

Bagozzi, R. P., \& Yi, Y. (1988). On the evaluation of structural equation models Journal of the Academy of Marketing Science, 16(1), 74-94.

Bagozzi, R. P., Yi, Y., \& Phillips, L. W. (1991). Assessing construct validity in organizational research. Administrative Science Quarterly, 421-458.

Barney, J. B. (2001). Is the resource-based "view" a useful perspective for strategic management research? Yes. Academy of Management Review, 26(1), 41-56.

Baron, R. M., \& Kenny, D. A. (1986). The moderator-mediator variable distinction in social psychological research: Conceptual, strategic, and statistical considerations. Journal of Personality and Social Psychology, 51(6), 1173.

Barreda, A. A., Bilgihan, A., Nusair, K., \& Okumus, F. (2015). Generating brand awareness in online social networks. Computers in Human Behavior, 50 600-609.

Bharadwaj, S. G., Varadarajan, P. R., \& Fahy, J. (1993). Sustainable competitive advantage in service industries: A conceptual model and research propositions. The Journal of Marketing, 83-99.

Boso, N., Story, V. M., \& Cadogan, J. W. (2013). Entrepreneurial orientation, market orientation, network ties, and performance: Study of entrepreneurial firms in a developing economy. Journal of Business Venturing, 28(6), 708-727.

Capron, L., \& Hulland, J. (1999). Redeployment of brands, sales forces, and general marketing management expertise following horizontal acquisitions: A resource-based view. The Journal of Marketing, 41-54.

Cervellon, M.-C., \& Galipienzo, D. (2015). Facebook pages content, does it really matter? Consumers' responses to luxury hotel posts with emotional and informational content. Journal of Travel \& Tourism Marketing, 32(4), 428-437.

Chang, W., Park, J. E., \& Chaiy, S. (2010). How does CRM technology transform into organizational performance? A mediating role of marketing capability. Journal of Business Research, 63(8), 849-855.

Chen, Y., Fay, S., \& Wang, Q. (2011). The role of marketing in social media: How online consumer reviews evolve. Journal of Interactive Marketing, 25(2), 85-94.

Cowling, M., Liu, W., Ledger, A., \& Zhang, N. (2015). What really happens to small and medium-sized enterprises in a global economic recession? UK evidence on sales and job dynamics. International Small Business Journal, 33(5), 488-513.

Davcik, N. S., \& Sharma, P. (2016). Marketing resources, performance, and competitive advantage: A review and future research directions. Journal of Business Research, 69(12), 5547-5552.

Durkin, M., McGowan, P., \& McKeown, N. (2013). Exploring social media adoption in small to medium-sized enterprises in Ireland. Journal of Small Business and Enterprise Development, 20(4), 716-734.

Economics, O. (2015). The economic contribution of the UK hospitality industry. A report prepared for British Hospitality Association.

Fraj, E., Matute, J., \& Melero, I. (2015). Environmental strategies and organizational competitiveness in the hotel industry: The role of learning and innovation as determinants of environmental success. Tourism Management, 46, 30-42.

Gannon, J. M., Roper, A., \& Doherty, L. (2015). Strategic human resource management: Insights from the international hotel industry. International Journal of Hospitality Management, 47, 65-75.

Garrido-Moreno, A., \& Lockett, N. (2016). Social media use in European hotels: Benefits and main challenges. Tourism \& Management Studies, 12(1).

Gensler, S., Völckner, F., Liu-Thompkins, Y., \& Wiertz, C. (2013). Managing brands in the social media environment. Journal of Interactive Marketing, 27(4), 242-256.

Guizzardi, A. Guizzardi, A., Monti, A., Monti, A., Ranieri, E., \& Ranieri, E. (2016). Rating hotel quality for corporate business travel departments. International Journal of Contemporary Hospitality Management, 28(12), 2842-2863.

Hair, J. F., Sarstedt, M., Ringle, C. M., \& Mena, J. A. (2012). An assessment of the use of partial least squares structural equation modeling in marketing research. Journal of the Academy of Marketing Science, 40(3), 414-433.

Hajli, M. (2013). A research framework for social commerce adoption. Information 
Management \& Computer Security, 21(3), 144-154.

Hajli, M. N. (2014). A study of the impact of social media on consumers. International Journal of Market Research, 56(3), 387-404.

Hajli, N. (2015). Social commerce constructs and consumer's intention to buy. International Journal of Information Management, 35(2), 183-191.

Hajli, M. N., \& Lin, X. (2014). Developing tourism education through social media. Tourism Planning \& Development, 11(4), 405-414.

Harrigan, P., Evers, U., Miles, M., \& Daly, T. (2017). Customer engagement with tourism social media brands. Tourism Management, 59, 597-609.

Harrington, R. J., \& Ottenbacher, C. M. (2011). Strategic management: An analysis of its representation and focus in recent hospitality research. International Journa of Contemporary Hospitality Management, 23(4), 439-462.

Harris, L., Rae, A., \& Misner, I. (2012). Punching above their weight: The changing role of networking in SMEs. Journal of Small Business and Enterprise Development, 19(2), 335-351.

Hogan, S. J., \& Coote, L. V. (2014). Organizational culture, innovation, and performance: A test of Schein's model. Journal of Business Research, 67(8), 1609-1621.

Hooley, G. J., Greenley, G. E., Cadogan, J. W., \& Fahy, J. (2005). The performance impact of marketing resources. Journal of Business Research, 58(1), 18-27.

Hudson, S., Huang, L., Roth, M. S., \& Madden, T. J. (2016). The influence of socia media interactions on consumer-brand relationships: A three-country study of brand perceptions and marketing behaviors. International Journal of Research in Marketing, 33(1), 27-41.

Hudson, S., \& Thal, K. (2013). The impact of social media on the consumer decision process: Implications for tourism marketing. Journal of Travel \& Tourism Marketing, 30(1-2), 156-160.

Hur, K., Kim, T. T., Karatepe, O. M., \& Lee, G. (2017). An exploration of the factors influencing social media continuance usage and information sharing intentions among Korean travellers. Tourism Management, 63, 170-178.

Jeong, M., \& Mindy Jeon, M. (2008). Customer reviews of hotel experiences through consumer generated media (CGM). Journal of Hospitality \& Leisure Marketing, $17(1-2), 121-138$.

Jöreskog, K. G., \& Sörbom, D. (1996). LISREL 8: User's reference guide. Scientific Software International.

Kaplan, A. M., \& Haenlein, M. (2010). Users of the world, unite! the challenges and opportunities of Social Media. Business Horizons, 53(1), 59-68.

Keller, K. L. (1993). Conceptualizing, measuring, and managing customer-based brand equity. The Journal of Marketing, 1-22.

Kim, A. J., \& Johnson, K. K. (2016). Power of consumers using social media: Examining the influences of brand-related user-generated content on Facebook. Computers in Human Behavior, 58, 98-108.

Kim, W. G., Li, J. J., \& Brymer, R. A. (2016). The impact of social media reviews on restaurant performance: The moderating role of excellence certificate. International Journal of Hospitality Management, 55, 41-51.

Kim, W. G., Lim, H., \& Brymer, R. A. (2015). The effectiveness of managing social media on hotel performance. International Journal of Hospitality Management 44, 165-171.

Kim, S., \& Park, H. (2013). Effects of various characteristics of social commerce (scommerce) on consumers' trust and trust performance. International Journal of Information Management, 33(2), 318-332. https://doi.org/10.1016 .ijinfomgt.2012.11.006.

Kline, R. B. (1998). Software review: Software programs for structural equation modeling: Amos, EQS, and LISREL. Journal of Psychoeducational Assessment, 16(4), 343-364.

Kumar, V., Bhaskaran, V., Mirchandani, R., \& Shah, M. (2013). Practice prize winner-creating a measurable social media marketing strategy: Increasing the value and ROI of intangibles and tangibles for hokey pokey. Marketing Science, 32(2), 194-212.

Ladhari, R., \& Michaud, M. (2015). eWOM effects on hotel booking intentions, attitudes, trust, and website perceptions. International Journal of Hospitality Management, 46, 36-45.

Ladkin, A., \& Buhalis, D. (2016). Online and social media recruitment: Hospitality employer and prospective employee considerations. International Journal of Contemporary Hospitality Management, 28(2), 327-345.

Leonidou, L. C., Leonidou, C. N., Fotiadis, T. A., \& Zeriti, A. (2013). Resources and capabilities as drivers of hotel environmental marketing strategy: Implications for competitive advantage and performance. Tourism Management, 35, 94-110.

Litvin, S. W., Goldsmith, R. E., \& Pan, B. (2008). Electronic word-of-mouth in hos pitality and tourism management. Tourism Management, 29(3), 458-468.

MacKinnon, D. P., Lockwood, C. M., Hoffman, J. M., West, S. G., \& Sheets, V. (2002) A comparison of methods to test mediation and other intervening variable effects, Psychological Methods, 7(1), 83.

Marco-Lajara, B., del Carmen Zaragoza-Sáez, P., Claver-Cortés, E., Úbeda-García, M., \& García-Lillo, F. (2017). Tourist districts and internationalization of hotel firms Tourism Management, 61, 451-464.

Martínez-Román, J. A. Tamayo, J. A., Gamero, J., \& Romero, J. E. (2015). Innovativeness and business performances in tourism SMEs. Annals of Tourism Research, 54, 118-135.

Melián-González, S., \& Bulchand-Gidumal, J. (2016). A model that connects information technology and hotel performance. Tourism Management, 53, 30-37.

Merrilees, B., Rundle-Thiele, S., \& Lye, A. (2011). Marketing capabilities: Antecedents and implications for B2B SME performance. Industrial Marketing Management, 40(3), 368-375.

Michaelidou, N., Siamagka, N. T., \& Christodoulides, G. (2011). Usage, barriers and measurement of social media marketing: An exploratory investigation of smal and medium B2B brands. Industrial Marketing Management, 40(7), 1153-1159.

Moorman, C., \& Rust, R. T. (1999). The role of marketing. The Journal of Marketing, 180-197.

Morgan, N. A. (2012). Marketing and business performance. Journal of the Academy of Marketing Science, 40(1), 102-119.

Morgan, N. A., Slotegraaf, R. J., \& Vorhies, D. W. (2009). Linking marketing capabilities with profit growth. International Journal of Research in Marketing, 26(4), 284-293.

Munar, A. M., \& Jacobsen, J. K. S. (2014). Motivations for sharing tourism experiences through social media. Tourism Management, 43, 46-54.

Naudé, P., Zaefarian, G., Tavani, Z. N., Neghabi, S., \& Zaefarian, R. (2014). The influence of network effects on SME performance. Industrial Marketing Management, 43(4), 630-641.

Nieves, J., \& Segarra-Ciprés, M. (2015). Management innovation in the hotel industry. Tourism Management, 46, 51-58.

Nisar, T. M., \& Whitehead, C. (2016). Brand interactions and social media: Enhancing user loyalty through social networking sites. Computers in Human Behavior, 62, $743-753$.

Nunnally, J. (1978). Psychometric methods. New York: McGraw-Hill.

Odoom, R., Odoom, R. Agbemabiese, G. C., Agbemabiese, G. C. Anning-Dorson, T. Anning-Dorson, T., ... Mensah, P. (2017). Branding capabilities and SME performance in an emerging market: The moderating effect of brand regulations. Marketing Intelligence \& Planning, 35(4), 473-487.

Okazaki, S., Andreu, L., \& Campo, S. (2017). Knowledge sharing among tourists via social media: A comparison between Facebook and TripAdvisor. International Journal of Tourism Research, 19(1), 107-119.

O'Connor, P. (2008). User-generated content and travel: A case study on Tripadvisor Com. In Information and communication technologies in tourism 2008 (pp. 47-58).

Palacios-Marqués, D., Merigó, J. M., \& Soto-Acosta, P. (2015). Online social networks as an enabler of innovation in organizations. Management Decision, 53(9), 1906-1920.

Pappas, N., \& Apostolakis, A. (2016). Financial crisis and tourism Activity: Evidence from the UK. In Global dynamics in travel, tourism, and hospitality (pp. 190-207). IGI Global.

Pavlou, P. A. (2003). Consumer acceptance of electronic commerce: Integrating trust and risk with the technology acceptance model. International Journal of Electronic Commerce, 7(3), 101-134.

Pentina, I., Gammoh, B. S., Zhang, L., \& Mallin, M. (2013). Drivers and outcomes of brand relationship quality in the context of online social networks. International Journal of Electronic Commerce, 17(3), 63-86.

Peteraf, M. A. (1993). The cornerstones of competitive advantage: A resource-based view. Strategic Management Journal, 14(3), 179-191.

Ramanathan, R., Ramanathan, U., \& Zhang, Y. (2016). Linking operations, marketing and environmental capabilities and diversification to hotel performance: A data envelopment analysis approach. International Journal of Production Economics, 176, 111-122.

Rapp, A., Beitelspacher, L. S., Grewal, D., \& Hughes, D. E. (2013). Understanding social media effects across seller, retailer, and consumer interactions. Journal of the Academy of Marketing Science, 41(5), 547-566.

Ring, A., Tkaczynski, A., \& Dolnicar, S. (2016). Word-of-mouth segments: Online, offline, visual or verbal? Journal of Travel Research, 55(4), 481-492.

Roberts, D. L., \& Candi, M. (2014). Leveraging social network sites in new product development: Opportunity or hype? Journal of Product Innovation Management, 31(S1), 105-117.

Rosman, R., \& Stuhura, K. (2013). The implications of social media on customer relationship management and the hospitality industry. Journal of Management Policy and Practice, 14(3), 18.

Schaupp, L. C., \& Bélanger, F. (2013). The value of social media for small businesses. Journal of Information Systems, 28(1), 187-207.

Schniederjans, D., Cao, E. S., \& Schniederjans, M. (2013). Enhancing financial performance with social media: An impression management perspective. Decision Support Systems, 55(4), 911-918.

Seth, G. (2012). Analyzing the effects of social media on the hospitality industry.

Siamagka, N.-T., Christodoulides, G., Michaelidou, N., \& Valvi, A. (2015). Determinants of social media adoption by B2B organizations. Industrial Marketing Management, 51, 89-99.

Sigala, M. (2012). Web 2.0 and customer involvement in new service development: A framework, cases and implications in tourism. Paper presented at the Web.

Sigala, M., \& Chalkiti, K. (2012). Knowledge management and web 2.0: Preliminary findings from the Greek tourism industry. In Social media in travel, tourism and Hospitality: Theory, practice and cases (Vol. 261).

Sigala, M., \& Chalkiti, K. (2014). Investigating the exploitation of web 2.0 for knowledge management in the Greek tourism industry: An utilisation-importance analysis. Computers in Human Behavior, 30, 800-812.

Su, Z., Peng, J., Shen, H., \& Xiao, T. (2013). Technological capability, marketing capability, and firm performance in turbulent conditions. Management and Organization Review, 9(1), 115-138.

Su, L., Swanson, S. R., \& Chen, X. (2016). The effects of perceived service quality on repurchase intentions and subjective well-being of Chinese tourists: The mediating role of relationship quality. Tourism Management, 52, 82-95.

Tornatzky, L. G., Fleischer, M., \& Chakrabarti, A. K. (1990). Processes of technological innovation. Lexington Books.

Trainor, K. J., Andzulis, J. M., Rapp, A., \& Agnihotri, R. (2014). Social media technology usage and customer relationship performance: A capabilities-based 
examination of social CRM. Journal of Business Research, 67(6), 1201-1208.

Trusov, M., Bucklin, R. E., \& Pauwels, K. (2009). Effects of word-of-mouth versus traditional marketing: Findings from an internet social networking site. Journal of Marketing, 73(5), 90-102.

Walter, A., Auer, M., \& Ritter, T. (2006). The impact of network capabilities and entrepreneurial orientation on university spin-off performance. Journal of Business Venturing, 21(4), 541-567.

Wamba, S. F., \& Carter, L. (2016). Social media tools adoption and use by SMES: An empirical study. In Social media and Networking: Concepts, methodologies, tools, and applications (pp. 791-806). IGI Global.

Watson, J. (2007). Modeling the relationship between networking and firm performance. Journal of Business Venturing, 22(6), 852-874.

Watson, J. (2012). Networking: Gender differences and the association with firm performance. International Small Business Journal, 30(5), 536-558.

Wernerfelt, B. (1984). A resource-based view of the firm. Strategic Management Journal, 5(2), 171-180.

Wong, C. Y., \& Karia, N. (2010). Explaining the competitive advantage of logistics service providers: A resource-based view approach. International Journal of Production Economics, 128(1), 51-67.
Wood, R. C. (2017). Reflecting on some realities of consumer behaviour in the hospitality industry. The Routledge Handbook of Consumer Behaviour in Hospitality and Tourism, 69.

Xie, K. L., Xie, K. L., Zhang, Z., Zhang, Z., Zhang, Z., Zhang, Z., ... Lee, S. K. (2016). Effects of managerial response on consumer eWOM and hotel performance: Evidence from TripAdvisor. International Journal of Contemporary Hospitality Management, 28(9), 2013-2034.

Yen, C.-L. A., \& Tang, C.-H. H. (2015). Hotel attribute performance, eWOM motivations, and media choice. International Journal of Hospitality Management, 46, 79-88.

Yu, W., Ramanathan, R., \& Nath, P. (2014). The impacts of marketing and operations capabilities on financial performance in the UK retail sector: A resource-based perspective. Industrial Marketing Management, 43(1), 25-31.

Zeng, B., \& Gerritsen, R. (2014). What do we know about social media in tourism? A review. Tourism Management Perspectives, 10, 27-36.

Zhang, M., Guo, L., Hu, M., \& Liu, W. (2017). Influence of customer engagement with company social networks on stickiness: Mediating effect of customer value creation. International Journal of Information Management, 37(3), 229-240. 